\title{
Article \\ Genetic Parameters of Stem and Wood Traits in Full-Sib Silver Birch Families
}

\author{
Grace Jones ${ }^{1}\left(\mathbb{D}\right.$, Mateusz Liziniewicz ${ }^{2}\left(\mathbb{D}\right.$, Stergios Adamopoulos ${ }^{3, *} \mathbb{C}$ and Johan Lindeberg ${ }^{1}$ \\ 1 Department of Forestry and Wood Technology, Faculty of Technology, Linnaeus University, \\ Universitetsplatsen 1, 35252 Växjö, Sweden; grace.jones@lnu.se (G.J.); johan.lindeberg@lnu.se (J.L.) \\ 2 The Forest Research Institute of Sweden (Skogforsk), Ekebo 2250, 26890 Svalöv, Sweden; \\ mateusz.liziniewicz@skogforsk.se \\ 3 Division of Wood Science and Technology, Department of Forest Biomaterials and Technology, \\ Swedish University of Agricultural Sciences, P.O. Box 7008, 75007 Uppsala, Sweden \\ * Correspondence: stergios.adamopoulos@slu.se
}

Citation: Jones, G.; Liziniewicz, M.; Adamopoulos, S.; Lindeberg, J. Genetic Parameters of Stem and Wood Traits in Full-Sib Silver Birch Families. Forests 2021, 12, 159. https: / / doi.org/10.3390/f12020159

Academic Editors: Pekka Saranpää and Xiping Wang

Received: 29 December 2020

Accepted: 26 January 2021

Published: 28 January 2021

Publisher's Note: MDPI stays neutral with regard to jurisdictional claims in published maps and institutional affiliations.

Copyright: (c) 2021 by the authors. Licensee MDPI, Basel, Switzerland. This article is an open access article distributed under the terms and conditions of the Creative Commons Attribution (CC BY) license (https:// creativecommons.org/licenses/by/ $4.0 /)$.

\begin{abstract}
This study investigated heritability of stem and wood traits to improve Swedish silver birch (Betula pendula Roth.) through breeding. Birch is $12 \%$ of Sweden's forest area but mainly used for low value pulp or firewood. This paper applied non-destructive test (NDT) methods, and estimated traits' heritability $\left(h^{2}\right)$, to help breed birch for high value solid wood products. Two trials of 22 families were assessed at age 19 for stem diameter (DBH), stem straightness, rough brown bark height $(\mathrm{BH})$, grain angle (GA), Pilodyn penetration depth (Pilo) and acoustic velocity (AV). X-ray densitometry was performed on a subsample of radial cores taken at $1.3 \mathrm{~m}$ from the ground to get an average benchmark density. The $h^{2}$ values were moderate for GA (0.20 and 0.21) and Pilo (0.53 and 0.48) at the two sites, but the $h^{2}$ values for $\mathrm{AV}$ were low (0.05 and 0.30$)$. There were moderate genotypic correlations between $\mathrm{BH}$ and $\mathrm{DBH}(0.51-0.54)$. There were low genotypic and phenotypic correlations between NDT measurements and other traits so including NDT in birch breeding efforts should not inadvertently reduce size, stem or wood quality. The high genetic correlations between sites suggest that GA, Pilo and AV values were determined more by genotype than by environment.
\end{abstract}

Keywords: acoustic velocity; Betula pendula Roth.; grain angle; heritability; non-destructive testing; Pilodyn; stem quality

\section{Introduction}

Over 12\% of Sweden's productive forest volume is composed of birch (Betula spp.) [1]. The majority of harvested birch is used for pulp [2] or firewood production as it is considered to be low quality. The volume of high quality wood is presumably insufficient to sustainably supply a domestic wood products industry. Birch regularly occurs in forests managed for Norway spruce or Scots pine production [3] where there is limited interest in managing birch for high quality wood. These birches are scattered in pure or mixed softwood stands and naturally regenerated from unimproved material, especially during early succession stages, such as after clear-cutting or storm damage [3,4]. The current recommendations are to plant improved material and adopt specialized silvicultural practices to produce high-quality birch wood and increase the value of Sweden's birch stands.

The two main species of birch in Swedish forests are silver birch (B. pendula Roth.) and downy birch (B. pubescens Ehrh.), and are commonly treated as a single species for inventory and harvest [1]. Of these two species, downy birch is able to grow on compact or wet sites, while silver birch requires relatively fertile sites with appropriate levels of water for vigorous growth [5,6]. Silver birch has been found to have higher volume production [7], straighter form [8], and higher wood density [9]. Therefore, silver birch is of interest to the Swedish tree breeding program. The breeding program for silver birch started in the 1980s with the main intention to improve volume production, and then to improve stem 
form traits, e.g., straightness, and branch properties [10,11]. Currently, the genetic gain in volume production per hectare is about $12-15 \%$, with significant improvement of stem form traits.

The selection of superior genotypes in the birch breeding program occurs in the first quarter of a full rotation, which is usually 40 years long. Few studies wait until a stand is mature to assess trial performance [12], especially as size and growth rate can be measured in young stands. Height and diameter can be the selection criteria when the breeding objective is to improve volume growth [13]. Wood quality traits important for sawn lumber production have not been considered in the birch breeding program, apart from single studies regarding wood density and fiber traits important for pulp production [10,14]. A minor genotypic correlation was observed by Stener and Hedenberg [10] between diameter and density for silver birch. Unfavorable genotypic correlations like this have necessitated the inclusion of multiple selection traits in some conifer breeding programs [15-17]. Faster growth rates have also been found to reduce birch strength [18] and wood density [19,20] in unimproved material.

Birch breeding programs have previously not included solid wood traits due to labor intensive measurements, limited resources, the requirement for destructive assessment methods [10,21], and a preference for selection at young ages [22]. Modern non-destructive testing (NDT) tools have been commonly used to measure density [23-27] stiffness [27-30], and grain angle [31,32] in coniferous and Eucalyptus species, yet are seldom applied to birch. These NDT tools are convenient for the measurement of genetic field trials [33] as measurements can occur at early ages, accelerating breeding cycles without felling the trees $[22,34,35]$. These tools also tend to be rapid and easy to use [36-38] compared to lab based methods allowing for larger sample size, and in some cases save time and money.

Wood density is frequently used as a key predictor of lumber strength and stability [36,39]. Wood density and wood hardness in silver birch have been found to be strongly correlated [9]. Wood hardness can be rapidly and non-distractively assessed with the Pilodyn densitometer [40,41] and the measurement value indicates wood density [40]. The depth of Pilodyn penetration (Pilo) has been found to be heritable for Eucalyptus spp. [42,43], coniferous species [25,27] and Betula spp. [41]. Estimates of heritability are population specific and vary by site, so need to be assessed separately for each trial of interest. Heritability estimates for density tend to be higher than for size or stem quality traits, and generally above 0.3 [44], showing there is the potential to improve birch wood density through breeding. There are numerous studies comparing the ability of NDT tools to assess wood density $[36,39,45]$, and densitometry is commonly mentioned as a rapid and accurate contemporary method to gather detailed information on radial density variation. Although a single density value per stem is often sufficient to compare stands or families $[19,46]$, densitometry allows researchers to rapidly obtain high resolution density data [47].

Grain angle (GA), or the "slope of grain", is known to cause sawn lumber deformation during drying [48] and negatively influence wood strength [49,50]. The angle can be positive or negative depending on the alignment of the cells to the stem axis or along a piece of wood, where more extreme values are worse. GA can be assessed on standing trees by applying the scribe method on a large bark window [51], using a wedge grain angle gauge [52,53], or with laboratory based methods on core samples [38,54]. Heritability of grain angle can vary dramatically, from 0.0 to 1.0 between two species of Eucalyptus [43].

Stiffness, as described by the modulus of elasticity (MOE), can also have an impact on sawing and drying so it is an important wood quality trait for lumber producers [55]. Measuring acoustic velocity (AV) in the tree stem has been used for MOE prediction in conifers, and is correlated with lumber strength [56-58]. AV may also be related to GA [59] and seems to be correlated with the angle of the cellulose microfibrals (MFA) in the S2 layer of the cell wall $[60,61]$. Time-of-flight (ToF) tools are common forestry field tools, which can be used to test standing tree AV $[58,61]$. Measurements of resonance-based AV on logs and solid timber are strongly correlated with ToF measurements [62,63], and fairly well correlated with bending strength [37]. For Eucalyptus spp. there have been a wide range of 
heritability values for AV; from 0.16 to 0.74 [28] for E. nitens, 0.20 for E. pilularis [43] and 0.62 for E. dunnii [43].

The aim of this study was to investigate phenotypic and genetic variation in growth and wood properties in two clonal experiments at the mid-harvest age, established with clones from 22 full-sib silver birch families produced in the Swedish birch breeding program. Relationships between birch growth traits, external quality traits, and wood properties measured with NDT, were studied to find if an external trait were highly correlated with wood properties, and could then be used in the breeding program as selection criteria. Wood density was estimated by means of indirect and direct methods to determine if birch wood density can be measured indirectly by means of the Pilodyn. The hypothesis tested were that there is no relationship between average family diameter and wood density, i.e., selection for diameter is not decreasing biomass production, and that there is a strong relationship between Pilodyn measurements and wood densities determined from cores. Determining if NDT values are heritable, and that there is sufficient variation in values, was also a key objective in this study, as this relates to the hypothesis that wood quality traits can be included in the birch breeding programs.

\section{Materials and Methods}

The material used for this study was collected in two clonal trials with silver birch located in Hyssna $\left(57^{\circ} 29^{\prime} 40^{\prime \prime} \mathrm{N}, 12^{\circ} 33^{\prime} 55^{\prime \prime} \mathrm{E}\right)$ and Brunsberg $\left(61^{\circ} 28^{\prime} 45^{\prime \prime} \mathrm{N}, 13^{\circ} 92^{\prime} 77^{\prime \prime} \mathrm{E}\right)$, south to mid Sweden (Figure 1). Hyssna is generally considered to be the superior site for growth as average monthly temperatures range from -4 to $21^{\circ} \mathrm{C}$ and the average monthly rainfall varies from 39 to $80 \mathrm{~mm}$. Brunsberg has a slightly shorter growing season, average monthly temperatures ranging from -8 to $22^{\circ} \mathrm{C}$, and the average monthly rainfall fluctuates between 19 and $82 \mathrm{~mm}$ [64]. Both trials were fenced before planting to eliminate browsing. Both trials were planted in a $2 \times 2 \mathrm{~m}$ spacing in spring 1999 with one-year old material. The experimental design was a single-tree plot design where each tree is randomly assigned to a planting spot. Each tree's ID code, genotype and parent information was then associated with its location: tree number within row, row number within block, and block number. Not all genotypes were present in each block due to the incomplete blocking design. There was a buffer zone surrounding the trial. A total of 3534 and 2479 trees were planted in Hyssna and Brunsberg, respectively.

The planted material included clones from 22-full-sib families produced by crossing trees in the Swedish elite birch population. The elite population contains the 20 "best birch" clones for a deployment zone below $59.5^{\circ}$ latitude. The elite population was established to increase the genetic gain over four birch breeding populations delimited in southern Sweden. There were seven unique mother trees and ten unique father trees in the crosses, with no reciprocal crosses (see Appendix A Table A1). Any tree could be used as a mother and a father tree. One mother tree was used five times, two mothers were used four times, one mother was used three times, and three mothers were used twice. Three fathers were used three times, six fathers two times, and one father one time. There were between 28 and 35 planted genotypes per family/cross in Hyssna and between 8 and 34 in Brunsberg. There were between 2 and 9 individuals (ramets) per clone with an average of 4.6 individuals per clone. In addition, there were seedlings from two half-sib families and seedlings from three reference locations planted in the experiment.

The field measurements were performed on all stems at ages 6, 12 and 19 years for both sites. Diameter (DBH) was measured in the north-south direction at a height of $1.3 \mathrm{~m}$ from the stem base (breast height) for all trees. Height was measured at age 6 for all trees in both experiments. Hyssna was thinned between at 12 years and 19 years, reducing the number of stems by $30 \%$ during the first thinning. A summary of all measured traits are in Table 1, alongside units and trait descriptions. 

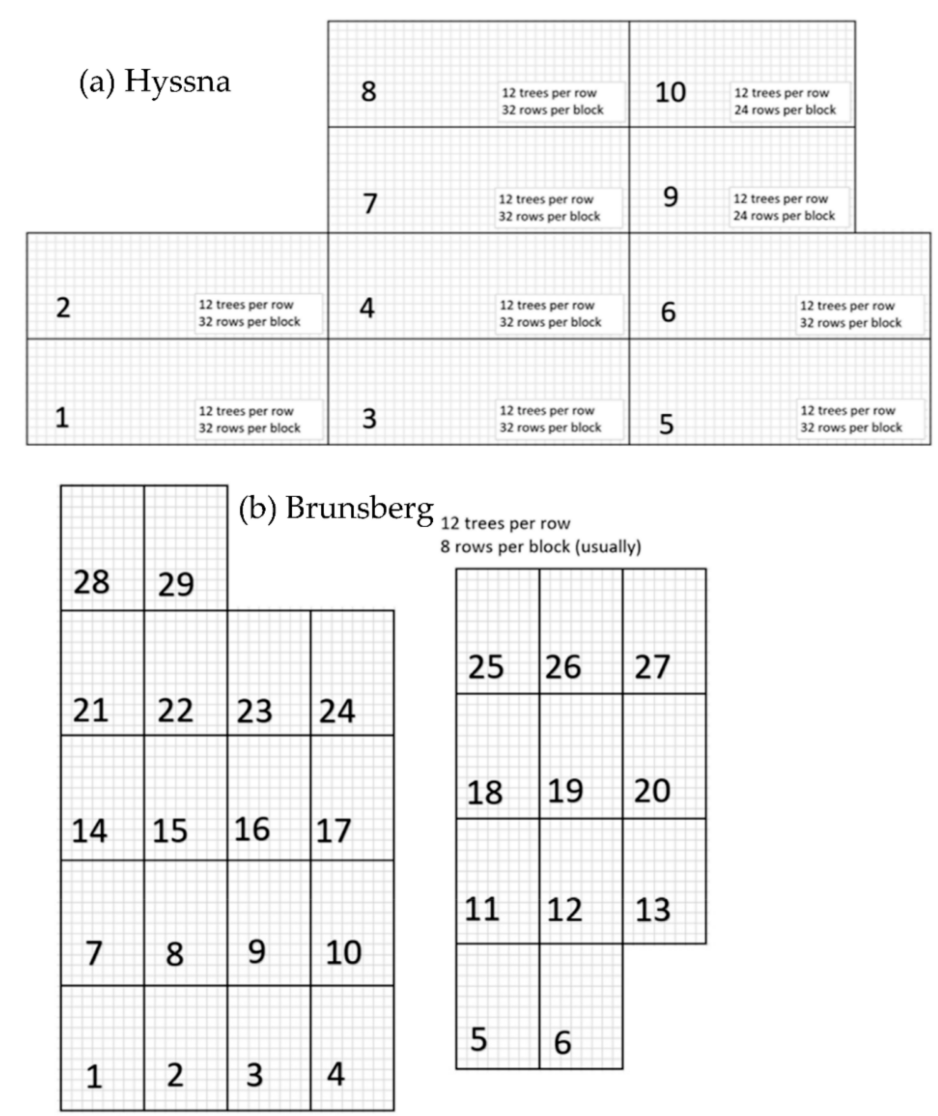

(c) Mid-south Sweden

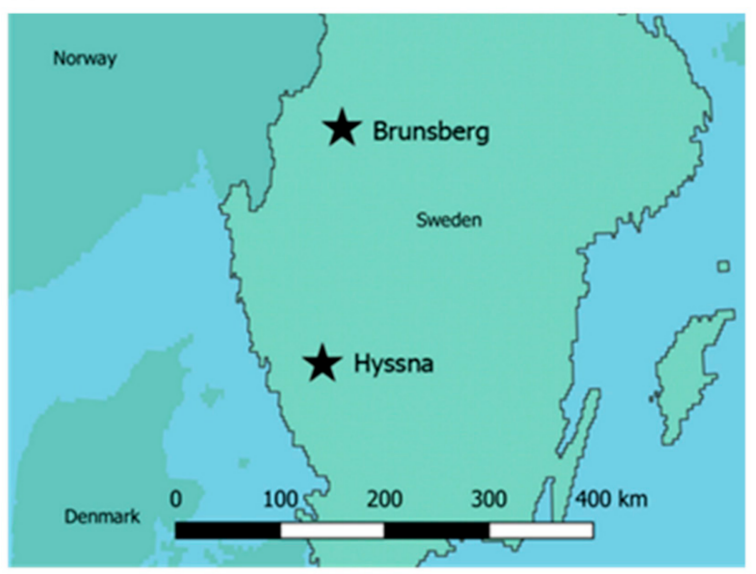

Figure 1. Site layout with block numbers for (a) Hyssna and (b) Brunsberg, each square is $2 \times 2 \mathrm{~m}$. Trial locations within Sweden (c) marked with stars and labelled. Country names are a smaller font size, blue area is sea, and grey outline is Sweden's coast.

Stem properties of all remaining trees were assessed in May 2018 when stems were 19 years old from the date of planting. Straightness was ranked on a scale from one to nine, where a score of nine indicated the best quality. This method has been a standard assessment tool for straightness in the birch breeding program $[10,53,65]$. The assessment of straightness considered any deviation from a cylinder in the bottom $8 \mathrm{~m}$ stem section, with a score of 5 considered by the assessor to be a stem representative of the site. A total of 1123 stems at Hyssna and 1410 stems at Brunsberg were ranked for straightness. The height of brown rough bark was measured from the stump base up to the height at which smooth silver bark dominated. Any defects or damages to the stem were recorded, and 
included features such as scars, breakages and stem lean. In addition, ramicorns (also referred to as epicornic branches) and multileaders were counted for each stem.

Table 1. Measurements and units for manual, visual and non-destructive field assessments.

\begin{tabular}{|c|c|c|}
\hline Measured Traits & Code & Description (units) \\
\hline \multicolumn{3}{|l|}{ Size traits } \\
\hline Height age 6 & $\mathrm{H}_{6}$ & Length of main stem $(\mathrm{cm})$ \\
\hline Diameter age 6 & $\mathrm{DBH}_{6}$ & Stem diameter at $1.3 \mathrm{~m}$ height $(\mathrm{mm})$ age 6 \\
\hline Diameter age 12 & $\mathrm{DBH}_{12}$ & Stem diameter at $1.3 \mathrm{~m}$ height $(\mathrm{mm})$ age 12 \\
\hline Diameter age 19 & $\mathrm{DBH}_{19}$ & Stem diameter at $1.3 \mathrm{~m}$ height $(\mathrm{mm})$ age 19 \\
\hline \multicolumn{3}{|l|}{ Stem form traits } \\
\hline Straightness & STR & Straightness score for stem below $8 \mathrm{~m}$ high (1-9) \\
\hline Bark height & $\mathrm{BH}$ & Height at which smooth bark dominates (cm) \\
\hline \multicolumn{3}{|l|}{ Wood quality traits } \\
\hline Grain angle & GA & Average grain angle measurement for north and south face at $1.3 \mathrm{~m}\left({ }^{\circ}\right)$ \\
\hline Pilodyn penetration & Pilo & Penetration depth by Pilodyn at $1.3 \mathrm{~m}$ height $(\mathrm{mm})$ \\
\hline Acoustic velocity & $\mathrm{AV}$ & $1,000,000$ divided by Fakopp $(\mathrm{ToF})$ value $(\mu$ s to travel $1 \mathrm{~m})$ is $\mathrm{AV}\left(\mathrm{m} \mathrm{s}^{-1}\right)$ \\
\hline Itrax benchmark wood density & DENS $_{\text {Itrax }}$ & $1.3 \mathrm{~m}$ core average wood density from Itrax densitometer and LignoVision ${ }^{\mathrm{TM}}\left(\mathrm{kg} \mathrm{m}^{-3}\right)$ \\
\hline
\end{tabular}

A subsample of trees was selected from the 22 control pollinated families, which had more than 20 individuals at both sites. Trees with severe defects, a DBH below $60 \mathrm{~mm}$, or with a rough bark height above $140 \mathrm{~cm}$, were excluded from the subsample. The 22 families then had 20 individuals selected randomly. The identity of the trees was tracked. If the tree has been damaged since the original assessment, it was not sampled, and then the next suitable stem was sampled if available. In this sense the sampling was not random, and some families had less than 20 trees sampled (at least 15 at both sites).

The subsample of stems was measured using NDT methods between August and September 2018. The grain angle, Pilodyn penetration depth, and AV along the stems were measured (Table 1). The Pilodyn 6J Forest (PROCEQ, Zurich, Switzerland) densitometer was applied twice to the north and south stem faces without bark removal [27] at breast height. The second Pilodyn measurement was taken a few centimeters to the left of the initial measurement, and both were averaged to get north and south values. A wedge grain angle gauge (grain angle meter) was used at breast height to measure grain angle on the north and south sides [52,53]. These values were averaged to get a single grain angle value per stem. Stem AV in the longitudinal direction was measured using the Fakopp TreeSonic Timer (FAKOPP Enterprise, Agfalva, Hungary) and converted from ToF ( $\mu \mathrm{s} \mathrm{m}^{-1}$ ) to $\mathrm{AV}\left(\mathrm{m} \mathrm{s}^{-1}\right)$ [66]. The TreeSonic timer was applied to the southern stem face between 0.8 and $1.8 \mathrm{~m}$, so that the $1 \mathrm{~m}$ length was centered on breast height. If there were any issues or uncertainties for any of the NDT tools, measurements were repeated and sometimes shifted a few centimeters to avoid defects and reduce operator error.

Average family diameters were used to select twelve families to take cores from; four families with the highest average, four with lowest average, and the four families with mid-range diameters. For each family, five trees per site were randomly selected. A $5 \mathrm{~mm}$ diameter core was taken at breast height from the south through to the north face of these trees. In total, 58 cores were collected from Hyssna and 72 cores from Brunsberg, and prepared using the method outlined by Hallingbäck et al. [67].

The Itrax scanning densitometer (Cox Analytical Systems, Mölndal, Sweden) was used to create x-ray images of all the cores as described in Bergsten et al. [68]. Later, the images were analysed using the computer program LIGNOVISION ${ }^{\mathrm{TM}}$ (Rinntech, Heidelberg, Germany). The program provided average light intensity (LI) values for a user defined area, which included a single annual ring. LI was then converted to wood density by using a function that included temperature, relative humidity, LI values for a calibration sample, and sample thickness [67]. Average wood density (DENS Itrax) was used for the remaining 
analysis, and is the average density value of all rings identified in LIGNOVISION ${ }^{\mathrm{TM}}$ for a given stem.

Variance and covariance components for the genetic analysis were estimated separately for each site using ASReml 4.0 [69] with a univariate linear mixed model in the following equation:

$$
y=X b+Z_{\alpha} \alpha+Z_{c} c+Z_{f} f+\varepsilon
$$

where $y$ is a vector of observed values, $b$ is a vector of fixed effects (i.e., blocks, plots), $\alpha$ is a vector of random additive genetic effects, $c$ is a vector of random effects of a clone within a full-sib family, $f$ is a vector of random effects of a full-sib family and $\varepsilon$ is a vector of random residuals. $X, Z_{\alpha}, Z_{c}$ and $Z_{f}$, are design matrices linking phenotypic observations to fixed and random effects. The first-order autocorrelation for parameters was tested in the model and kept if the model converged and the log likelihood improved.

Estimates of the individual tree narrow-sense heritability $\left(h^{2}\right)$ were calculated for each trait from the variance components obtained in the univariate analysis. Standard errors were estimated with the Taylor series expansion method.

$$
h_{i}^{2}=\frac{\hat{\sigma}_{A}^{2}}{\hat{\sigma}_{P}^{2}}=\frac{\hat{\sigma}_{A}^{2}}{\hat{\sigma}_{A}^{2}+\hat{\sigma}_{c}^{2}+\hat{\sigma}_{f}^{2}+\hat{\sigma}_{\varepsilon}^{2}}
$$

where for any trait $i: h_{i}^{2}$ is the narrow-sense heritability, $\hat{\sigma}_{A}^{2}$ is the additive genetic variance, $\hat{\sigma}_{P}^{2}$ is the total phenotypic variance $\left(\hat{\sigma}_{A}^{2}+\hat{\sigma}_{c}^{2}+\hat{\sigma}_{f}^{2}\right)$, and $\hat{\sigma}_{\varepsilon}^{2}$ is the total error variance. This value is often used to indicate the proportion of variation in a trait that cannot be attributed to site or phenotypic factors.

Phenotypic coefficients of variation (PCV) and genotypic coefficients of variation (GCV) were calculated for each trait using the following formulas:

$$
\begin{gathered}
\mathrm{PCV}=\frac{\sqrt{\sigma_{p}^{2}}}{\bar{x}} \times 10 \\
\mathrm{GCV}=\frac{\sqrt{\sigma_{A}^{2}}}{\bar{x}} \times 100
\end{gathered}
$$

where $\bar{x}$ is the general mean, $\sigma_{p}^{2}$ is the phenotypic variance and $\sigma_{A}^{2}$ is the additive genetic variance.

To estimate genetic correlations, the trait variance components and covariance components between pairs of traits were estimated using bivariate analysis. The bivariate model was an expansion of the univariate model to include a vector of values for two traits and matrices corresponding to fixed effect design and random effect design for each trait, respectively.

Variances and covariances of the random effects were estimated as:

$$
\operatorname{Var}\left[\begin{array}{c}
a \\
c \\
f \\
\varepsilon
\end{array}\right]=\left[\begin{array}{cccc}
G \otimes A & 0 & 0 & 0 \\
0 & C \otimes I & 0 & 0 \\
0 & 0 & F \otimes I & 0 \\
0 & 0 & 0 & R \otimes I
\end{array}\right]
$$

where $A$ is the numerator relationship matrix, $G$ is the additive genetic (co)variance matrix, $C$ is the clone (co)variance matrix, $F$ is the family $\operatorname{co(variance)~matrix,~} R$ is the residual (co)variance matrix, and $I$ is an identity matrix.

The $n \times n$ symmetric numerator relationship matrix $A$ in was structured as:

$$
A=\left[\begin{array}{ccc}
p_{11} & \ldots & p_{1 n} \\
\vdots & \ddots & \vdots \\
p_{n 1} & \ldots & p_{n n}
\end{array}\right]
$$


where $p_{i j}$ is the additive pedigree-based relationship between any pair of tree individuals $i$ and $j$ for all $n$ individuals included in the analysis. The $2 \times 2$ order symmetric matrices $G$, $C, F$ and $R$, are in turn structured as:

$$
\begin{aligned}
& G=\left[\begin{array}{cc}
\sigma_{a 1}^{2} & \sigma_{a 12} \\
\sigma_{a 12} & \sigma_{a 2}^{2}
\end{array}\right] \\
& C=\left[\begin{array}{cc}
\sigma_{c 1}^{2} & \sigma_{c 12} \\
\sigma_{c 12} & \sigma_{c 2}^{2}
\end{array}\right] \\
& F=\left[\begin{array}{cc}
\sigma_{f 1}^{2} & \sigma_{f 12} \\
\sigma_{f 12} & \sigma_{f 2}^{2}
\end{array}\right] \\
& R=\left[\begin{array}{cc}
\sigma_{\varepsilon 1}^{2} & \sigma_{\varepsilon 12} \\
\sigma_{\varepsilon 12} & \sigma_{\varepsilon 2}^{2}
\end{array}\right]
\end{aligned}
$$

where $\sigma_{a 1}^{2}, \sigma_{c 1}^{2}, \sigma_{f 1}^{2}, \sigma_{\varepsilon 1}^{2}$ and $\sigma_{a 2}^{2}, \sigma_{c 2}^{2}, \sigma_{f 2}^{2}, \sigma_{\varepsilon 2}^{2}$ are additive genetic, clone within family, fullsib family and residual variances for trait 1 and 2 , respectively. The $\sigma_{a 12}, \sigma_{c 12}, \sigma_{f 12}$, and $\sigma_{\varepsilon 12}$, are additive genetic, clonal within family, full-sib family and residual covariances between trait 1 and 2 .

Phenotypic $\left(\operatorname{cor}_{\mathrm{P}}\right)$ and genotypic $\left(\mathrm{cor}_{\mathrm{G}}\right)$ correlations between traits and age-age genotypic correlations $\left(R_{(x, y)}\right)$ were calculated as:

$$
R_{(x, y)}=\frac{c \hat{o} v_{(1,2)}}{\sqrt{\hat{\sigma}_{(1)}^{2} x \hat{\sigma}_{(2)}^{2}}}
$$

where $\hat{\sigma}_{(1)}^{2}$ and $\hat{\sigma}_{(2)}^{2}$ are the estimated phenotypic or genotypic variances for traits 1 and 2 or the same trait variances at two different ages, respectively, and côv $(1,2)$ is the estimated phenotypic or genotypic covariance $\left(\sigma_{a 12}\right)$ between traits 1 and 2 or between two different ages. These correlations indicate how similar two traits are, so that as one trait changes the other is likely to also change if the phenotype or genotype are linked. Values were recorded with a negative symbol if the correlation was negative.

The between site genetic correlations were estimated by compound variances for the linear mixed model and heterogeneous genetic variance within each site. The model used covariance parameterization [70] and was of the same general form as Equation (5) with the addition of random genetic site effects $Z_{s} s$; where $s$ is a vector of site random effects, and $Z_{S}$ is a design matrix linking the phenotypic observation to fixed and random effects.

A between-site genetic correlation of one is expected if the genetic influences on the trait are identical between sites, whereas a value of zero implies that the genetic effects on the trait are independent of the site. These are consistently referred to as genetic correlations to avoid confusion with the above genotypic correlations $\left(\operatorname{cor}_{\mathrm{G}}\right)$.

Graphs were produced using the statistics software R (version 3.6.3, R Core Team, Vienna, Austria) for Pilodyn north against Pilodyn south measurements, Itrax density against stem diameter, and Itrax density against Pilodyn penetration depth. $\mathrm{R}$ was also used to plot linear trend lines between the variables. Correlations between variables were calculated using the cor() function and the Pearson's correlation method, which assumes a linear relationship between variables and indicates the strength and direction of this relationship (from -1 to +1 ).

\section{Results}

\subsection{Descriptive Statistics, Heritability and Variability of Traits}

The average height of trees measured at age six was $71 \mathrm{~cm}$ for Hyssna and $47 \mathrm{~cm}$ for Brunsberg, with respective average diameters of 56 and $36 \mathrm{~mm}$ (Table 2). At 19 years old the diameters in Hyssna and Brunsberg were 110 and $98 \mathrm{~mm}$, respectively. These size traits (height and diameters) had heritability estimates around 0.2 for Hyssna and below 0.1 for 
Brunsberg. PCVs were higher for Brunsberg (maximum 42\%) than for Hyssna (maximum $27 \%$ ), yet Hyssna had higher GCVs (maximum 13.5\%) than Brunsberg (maximum 7.8\%). Height at age 6 had the lowest coefficients of variation for any size trait, with PCV values of $15 \%$ at Hyssna and $28 \%$ at Brunsberg, and a GCV of $6.3 \%$ at both sites.

Table 2. Measurements and units for manual, visual and non-destructive field assessments.

\begin{tabular}{|c|c|c|c|c|c|c|c|c|c|c|c|c|c|c|c|c|}
\hline \multirow{2}{*}{$\begin{array}{c}\text { Traits } \\
\text { Site }\end{array}$} & \multicolumn{2}{|c|}{$\mathbf{N}$} & \multicolumn{2}{|c|}{ Mean } & \multicolumn{2}{|c|}{ Min } & \multicolumn{2}{|c|}{ Max } & \multicolumn{2}{|c|}{ PCV (\%) } & \multicolumn{2}{|c|}{$h^{2}$} & \multicolumn{2}{|c|}{ SE (\%) } & \multicolumn{2}{|c|}{ GCV (\%) } \\
\hline & $\mathrm{H}$ & B & $\mathrm{H}$ & B & $\mathrm{H}$ & B & $\mathrm{H}$ & $\mathrm{B}$ & $\mathrm{H}$ & B & $\mathrm{H}$ & B & $\mathrm{H}$ & B & $\mathrm{H}$ & B \\
\hline $\mathrm{H}_{6}(\mathrm{~mm})$ & 3360 & 2279 & 71 & 47 & 27 & 8 & 105 & 80 & 15 & 28 & 0.2 & 0.07 & 0.02 & 0.01 & 6.3 & 6.3 \\
\hline $\mathrm{DBH}_{6}(\mathrm{~mm})$ & 3360 & 2262 & 56 & 36 & 11 & 2 & 111 & 82 & 27 & 42 & 0.19 & 0.04 & 0.02 & 0.01 & 11.1 & 7.8 \\
\hline $\mathrm{DBH}_{12}(\mathrm{~mm})$ & 3320 & 2230 & 83 & 65 & 17 & 7 & 157 & 163 & 25 & 32 & 0.28 & 0.05 & 0.02 & 0.01 & 13.5 & 7.6 \\
\hline $\mathrm{DBH}_{19}(\mathrm{~mm})$ & 2362 & 1409 & 110 & 98 & 17 & 20 & 211 & 194 & 25 & 28 & 0.21 & 0.09 & 0.04 & 0.03 & 10.6 & 7.1 \\
\hline STR (1-9) & 1123 & 1410 & 5 & 4.6 & 1 & 1 & 8 & 8 & 18.1 & 20.1 & 0.23 & 0.22 & 0.03 & 0.03 & 8.4 & 9.4 \\
\hline $\mathrm{BH}(\mathrm{cm})$ & 1141 & 1390 & 67 & 46 & 0 & 10 & 280 & 240 & 65 & 74 & 0.44 & 0.39 & 0.04 & 0.03 & 2.4 & 45.4 \\
\hline $\mathrm{GA}\left({ }^{\circ}\right)$ & 440 & 393 & -1.8 & -1.5 & -6.3 & -6.3 & 2.5 & 2.8 & 63 & 74 & 0.20 & 0.21 & 0.03 & 0.03 & 31 & 51.9 \\
\hline Pilo (mm) & 442 & 453 & 17.6 & 17.2 & 13.8 & 8.3 & 23.2 & 24.1 & 7.7 & 10.2 & 0.53 & 0.48 & 0.06 & 0.07 & 5.8 & 7.1 \\
\hline $\mathrm{AV}\left(\mathrm{m} \mathrm{s}^{-1}\right)$ & 450 & 453 & 4184 & 4237 & 6135 & 4717 & 3636 & 3165 & 4.8 & 5.5 & 0.05 & 0.3 & 0.04 & 0.08 & 0.6 & 1.6 \\
\hline DENS $_{\text {Itrax }}\left(\mathrm{kg} \mathrm{m}^{-3}\right)$ & 115 & 151 & 431 & 444 & 329 & 358 & 520 & 566 & 8 & 7.1 & NA & NA & NA & NA & NA & NA \\
\hline
\end{tabular}

The mean score for stem straightness (STR) was 5 at Hyssna and 4.6 at Brunsberg. The related PCVs were 18.1 and $20.1 \%$ and GCVs were 8.4 and 9.4\%. Heritability for STR was 0.23 at Hyssna and 0.22 at Brunsberg. The average bark height $(\mathrm{BH})$ was $67 \mathrm{~cm}$ at Hyssna and $46 \mathrm{~cm}$ and Brunsberg, with PCVs of 65 and 74\%, and GCVs of 2.4 and $45.4 \%$. Heritability estimates for BH were 0.44 at Hyssna and 0.39 at Brunsberg. For these stem form traits, coefficients of variation were lower at Hyssna and heritibilities were slightly lower at Brunsberg.

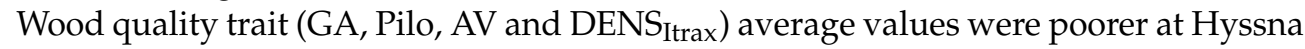
than Brunsberg: GA was $-1.8^{\circ}$ and $-1.3^{\circ}$, Pilo was 17.6 and $17.2 \mathrm{~mm}$, AV was 4184 and $4237 \mathrm{~m} \mathrm{~s}^{-1}$, and DENS Itrax $_{\text {was }} 431$ and $444 \mathrm{~kg} \mathrm{~m}^{-3}$ (for Hyssna and Brunsberg, respectively). GA had PCVs above $60 \%$ and GCVs above $30 \%$ at both sites, and heritabilities were 0.20 at Hyssna and 0.21 at Brunsberg. Pilo had a PCV of $7.7 \%$ and GCV of $5.8 \%$ at Hyssna, and a PCV of $10.2 \%$ and GCV of $7.1 \%$ at Brunsberg. Heritability for Pilo was around 0.50 at both sites. Heritability for AV was non-existant at Hyssna (0.05) but moderate at Brunsberg (0.30), which also had PCVs around 5\% and GCVs below 2\%, the lowest of all

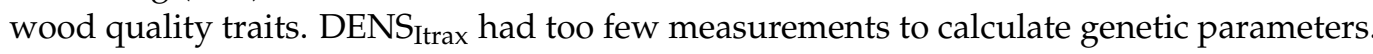

\subsection{Phenotypic and Genotypic Correlations between Traits}

Phenotypic correlations (cor $)$ were above 0.83 between diameters $\left(\mathrm{DBH}_{6}, \mathrm{DBH}_{12}\right.$, and $\mathrm{DBH}_{19}$ ), and above 0.7 between $\mathrm{H}_{6}$ and diameters (Table 3). Genotypic correlations (cor $_{\mathrm{G}}$ ) were above 0.9 between diameters $\left(\mathrm{DBH}_{6}, \mathrm{DBH}_{12}\right.$, and $\left.\mathrm{DBH}_{19}\right)$, and above 0.55 between $\mathrm{H}_{6}$ and diameters (Table 3).

Table 3. Phenotypic (above the diagonal) and additive genotypic (below the diagonal) correlations between traits. $\mathrm{H}$ is Hyssna and B is for Brunsberg.

\begin{tabular}{|c|c|c|c|c|c|c|c|c|c|c|c|c|c|c|c|c|}
\hline \multirow{2}{*}{$\begin{array}{l}\text { Traits } \\
\text { Site }\end{array}$} & \multicolumn{2}{|c|}{$\mathrm{H}_{6}$} & \multicolumn{2}{|c|}{$\mathrm{DBH}_{6}$} & \multicolumn{2}{|c|}{$\mathrm{DBH}_{12}$} & \multicolumn{2}{|c|}{$\mathrm{DBH}_{19}$} & \multicolumn{2}{|c|}{ BH } & \multicolumn{2}{|c|}{ GA } & \multicolumn{2}{|c|}{ Pilo } & \multicolumn{2}{|c|}{ AV } \\
\hline & $\mathrm{H}$ & B & $\mathrm{H}$ & B & $\mathrm{H}$ & B & $\mathrm{H}$ & B & $\mathrm{H}$ & B & $\mathrm{H}$ & B & $\mathrm{H}$ & B & $\mathrm{H}$ & B \\
\hline $\mathrm{H}_{6}$ & & & 0.84 & 0.93 & 0.80 & 0.82 & 0.70 & 0.76 & 0.32 & 0.38 & -0.04 & -0.01 & -0.04 & -0.01 & -0.18 & -0.27 \\
\hline $\mathrm{DBH}_{6}$ & 0.68 & 0.67 & & & 0.92 & 0.90 & 0.84 & 0.83 & 0.54 & 0.51 & 0.03 & -0.03 & 0.17 & 0.02 & 0.10 & -0.10 \\
\hline $\mathrm{DBH}_{12}$ & 0.71 & 0.55 & 0.95 & 0.90 & \multicolumn{2}{|c|}{1} & 0.94 & 0.94 & 0.51 & 0.51 & -0.03 & -0.04 & 0.12 & 0.12 & 0.03 & -0.07 \\
\hline $\mathrm{DBH}_{19}$ & 0.73 & 0.61 & 0.90 & 0.99 & 0.98 & 0.99 & \multicolumn{2}{|c|}{1} & 0.53 & 0.51 & -0.16 & -0.12 & 0.08 & 0.18 & 0.00 & -0.11 \\
\hline $\mathrm{BH}$ & 0.08 & -0.11 & 0.5 & 0.35 & 0.42 & 0.23 & 0.37 & 0.25 & \multicolumn{2}{|c|}{1} & -0.15 & -0.07 & 0.04 & -0.12 & 0.25 & 0.09 \\
\hline GA & 0.67 & 0.28 & 0.85 & 0.24 & 0.97 & 0.45 & 0.99 & 0.49 & 0.29 & 0.05 & \multicolumn{2}{|c|}{1} & 0.15 & 0.06 & -0.16 & -0.12 \\
\hline Pilo & -0.22 & -0.19 & -0.03 & -0.19 & -0.15 & -0.07 & -0.34 & 0.02 & -0.17 & -0.36 & -0.18 & -0.04 & \multicolumn{2}{|c|}{1} & 0.16 & 0.09 \\
\hline AV & 0.37 & -0.61 & -0.16 & -0.25 & -0.06 & -0.11 & -0.11 & 0.04 & -0.11 & 0.29 & -0.46 & -0.07 & -0.12 & -0.10 & \multicolumn{2}{|c|}{1} \\
\hline
\end{tabular}


Diameters had high cor $_{\mathrm{P}}$ with $\mathrm{BH}$ (above 0.5), and moderate cor $_{\mathrm{G}}$ with $\mathrm{BH}(0.23-0.5)$. Other $\operatorname{cor}_{P}$ values were low between size traits, bark height and wood quality traits, with most $\operatorname{cor}_{P}$ values close to \pm 0.1 , and the largest $\operatorname{cor}_{P}(-0.27)$ between $\mathrm{AV}$ and $\mathrm{H}_{6}$ at Brunsberg.

The cor $\mathrm{P}$ between $\mathrm{BH}$ and wood quality traits were low, ranging from 0.04 for Pilo at Brunsberg to 0.25 for $\mathrm{AV}$ at Hyssna. $\mathrm{BH}$ had slightly higher cor $_{\mathrm{G}}$ values with Pilo $(-0.17$ and -0.36$)$ and AV (-0.11 and 0.29), for Hyssna and Brunsberg, respectively.

Wood quality traits (GA, Pilo, and AV) generally had low $\operatorname{cor}_{P}(-0.03$ to 0.16$)$ and cor $_{G}$ (around 0.1$)$ with other wood quality traits. There was a moderate $(-0.46)$ cor $_{G}$ between GA and AV at Hyssna, but a low $\operatorname{cor}_{G}$ value for Brunsberg (-0.07). GA had low to high (0.24 to 0.99$)$ cor $_{G}$ with size traits.

\subsection{Correlations between Sites and Measurements}

The between site correlation for $\mathrm{H} 6$ was 0.76 the highest for any size trait (Table 4$)$. The same correlation for DBH6 was 0.44, DBH12 was 0.47, and DBH19 0.35. The between-site correlations were higher for stem form traits (above 0.6) than for size traits (Table 4). Wood quality traits had high between-site correlations; 0.96 for GA, 0.82 for Pilo, and 1.00 for AV.

Table 4. Genetic correlations between the same traits measured at two sites (Hyssna and Brunsberg). $\mathrm{SE}$ is standard error.

\begin{tabular}{ccc}
\hline Trait & Genetic Correlation between Hyssna and Brunsberg & SE \\
\hline $\mathrm{H}_{6}$ & 0.757 & 0.104 \\
$\mathrm{DBH}_{6}$ & 0.444 & 0.149 \\
$\mathrm{DBH}_{12}$ & 0.466 & 0.127 \\
$\mathrm{DBH}_{19}$ & 0.350 & 0.13 \\
$\mathrm{STR}$ & 0.824 & 0.113 \\
$\mathrm{BH}$ & 0.673 & 0.069 \\
$\mathrm{GA}$ & 0.956 & 0.117 \\
Pilo & 0.815 & 0.098 \\
$\mathrm{AV}$ & 0.998 & $<0.001$ \\
\hline
\end{tabular}

The average Pilodyn readings for the north and south stem faces had a correlation of 0.809 for Hyssna and 0.823 for Brunsberg (Figure 2). Given the strong correlation, an average of the north and south Pilodyn readings for each stem (Pilo) is used elsewhere

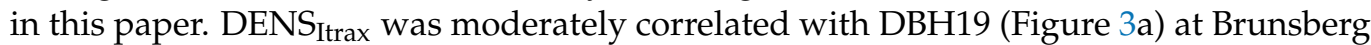

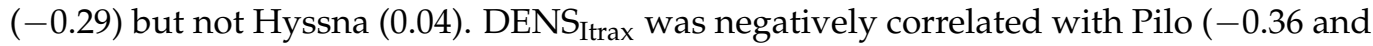
$-0.46)$, for Hyssna and Brunsberg, respectively (Figure 3b).

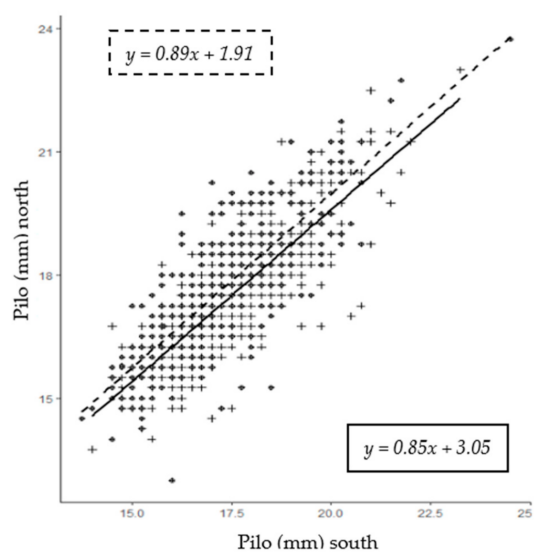

Figure 2. Plot comparing average north and south Pilodyn penetration at Hyssna (cross, solid line) and Brunsberg (circle, dashed line). Trend line equations are displayed for Hyssna (solid border) and Brunsberg (dashed border). 

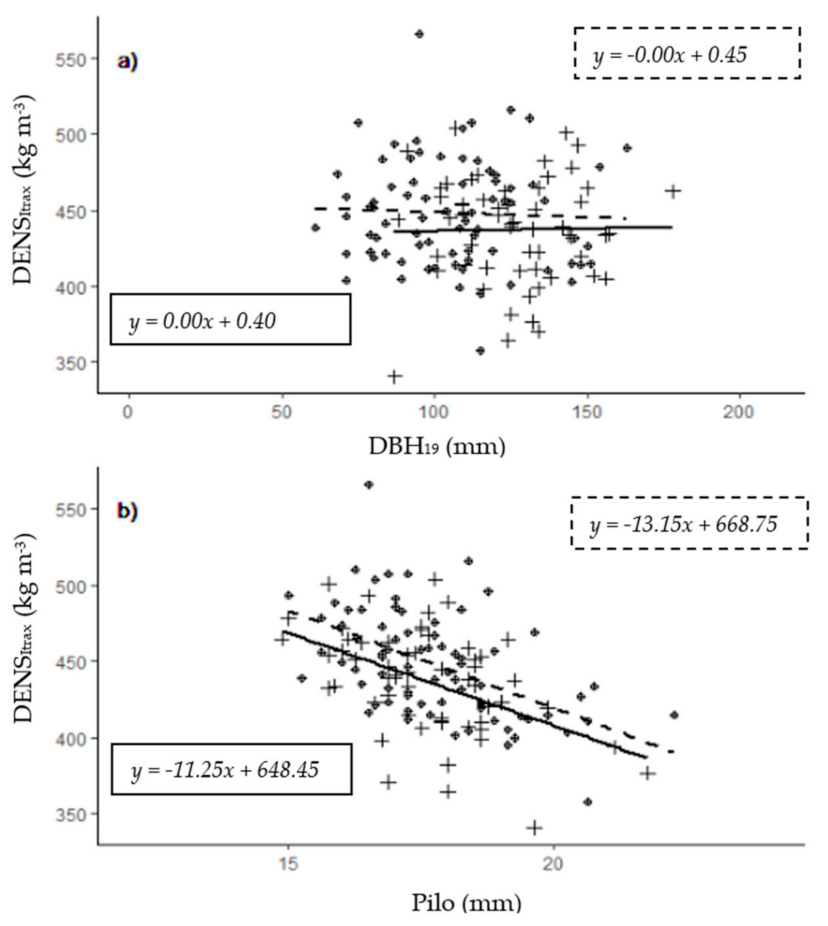

Figure 3. Relationship between diameter at age 19 (a) or Pilodyn penetration (b) with average wood density from Itrax at Hyssna (cross, solid line) and Brunsberg (circle, dashed line). Trend line equations are displayed for Hyssna (solid border) and Brunsberg (dashed border).

\section{Discussion}

Since the 1980s, the Swedish breeding program has managed to increase volume production per area $\left(\mathrm{m}^{3} \mathrm{ha}^{-1}\right)$ by $15 \%$ and improved overall stem quality, compared to unimproved silver birch regeneration [13]. Unfortunately, the annual birch seedling production is less than $1 \%$ of the Norway spruce or Scots pine seedling production [71], reflecting the still limited interest in planting improved birch. This gap can be reduced if opportunities and markets are developed, and product education occurs, to encourage the use of birch wood [72]. Birch is believed to have lower production than the planted spruce and pine $[73,74]$ and be too low quality for solid products, so any activity to improve growth rates, form or perception, could increase the amount of birch planted. As the use of broadleaved species is increasingly promoted in Sweden to meet goals for biodiversity [75], plantation management will need to focus on maximizing production value from broadleaf trees, both in mixtures and pure stands. For birch, this will include silvicultural choices such as improved genetic material and establishment methods.

It is important to test planting material across sites (GxE correlation) located in different conditions [76]. In our study, there were between site differences indicating that variables not related to genetics might influence the performance of genotypes. Phenotypic coefficients of variation were higher at Brunsberg than Hyssna. Brunsberg stem form traits and wood quality traits had higher genotypic coefficients of variation, while the reverse was true for size traits; diameters and height had lower genotypic variation at Hyssna. Higher genotypic variation is desirable in breeding programs as it indicates these traits have potential for improvement, and higher variability can make selection progress rapidly [77]. There were also high genetic correlations between sites for height, stem form, and wood quality traits, while diameters had moderate (below 0.5 ) between site genetic correlations. High between-site genetic correlations suggest that the best families will perform well at both sites as family performance rankings were stable.

The heritabilities for size traits reported here were slightly lower than in other genetics studies of silver birch in Sweden. In the study by Stener and Jansson [78], average heritibilities for diameter (0.29) and height (0.32) of open-pollinated silver birch trees at age 7 were 
similar to those in this study (0.04-0.28) and varied between sites. Gailis et al. [79] studied open-pollinated silver birch in Latvia at ages 10 and 14 years [79], and had heritibilities above 0.12 for diameter and 0.30 for height. This paper's heritabilities were much lower than those found by Skrøppa and Solvin [80] at age 16 for height (0.38) and diameter (0.81) for full and half-sib families in Norway. The genotypes used by Skroppa and Solvin were produced from a $9 \times 9$ diallel mating design [80], which may explain the relatively large differences in heritabilities compared to our study. Here, the moderately high heritability, and reasonable variability, indicate that selection for size traits is possible in the studied population.

Of the stem form traits, straightness has been more frequently assessed $[78,79]$ than any bark metric [81]. For these other studies of silver birch [78,79], heritability for straightness ranged from 0.02 to 0.45 and was generally lower than for size traits. The heritibilities for straightness at Hyssna and Brunsberg, were above 0.2 in our study and would fit within this range of values. Viherä-Aarnio and Velling [81] measured bark thickness of 22-year-old silver birch in a provenance trial. They found that seed origin latitude was related to bark thickness, yet, unfortunately, did not provide heritabilities. In our study, heritability for bark height was very high at both Hyssna and Brunsberg, but genetic variation was very low at Hyssna. The results of this study suggest stem form traits can be improved through breeding. Stem straightness has previously been considered in the breeding program for birch $[10,78]$. The high genotypic variation and heritability of rough bark height makes this trait interesting and relatively easy to include in breeding, if there is enough commercial interest.

Grain angle heritability using the wedge grain angle meter has been commonly assessed for conifer species [31,32,52,82], yet it is difficult to find any hardwood species genetics trials which considered grain angle [83]. For 9-year-old open-pollinated family trials of Eucalyptus in Australia, E. dunnii had a heritability for grain angle of 1.0 [83] compared to 0.0 for E. pilularis [43], which is a large range of heritability estimates between species. The heritability for silver birch wood density in an 11-year-old Swedish clonal trial [10] was 0.73, which was higher than for Pilo in this study. Liang et al., studied 60 halfsib B. platyphylla families in China [84] and found heritability estimates of 0.30 and 0.37 for air-dry and oven-dry wood density, respectively. The same paper reported heritability values for flexural strength (0.37) and elastic modulus (0.15), which could be comparable to this study's AV measurements but included the influence of wood density on stiffness [37]. It is common for wood quality traits to have higher heritability estimates than size traits [85] as size traits tend to be under strong environmental influence.

The NDT tools used in this study to indirectly assess wood quality traits had fairly high heritabilities. Pilo had high heritability estimates at both sites, but Pilo had less variation than GA, which had low-moderate (0.2) heritability values. AV heritability was moderate at Brunsberg but extremely low at Hyssna, and had the lowest genetic coefficients of variation for any trait. Therefore, the results of this study should be complemented with more observations of $B$. pendula solid wood quality traits to see if these results are species or population specific, and to confirm that they are not unusual. One benefit of this work, is that the sampled trees are still growing, and could be assessed again later to see how well early performance relates to log mechanical properties, or how relationships vary with age $[31,86]$. The assessment of wood mechanical properties with NDT tools was also rapid, so the methodology should be easy for other researchers to apply.

The phenotypic correlations between bark height and wood quality traits were moderate, and genotypic correlations were slightly stronger. The rough bark height could affect the NDT measurements despite stems with rough bark at $1.3 \mathrm{~m}$ being excluded from the sample. It would be worth exploring these relationships further as rough bark height can be rapidly measured. Viherä-Aarnio and Velling [81] related bark thickness to seed origin latitude in a 22-year-old silver birch progeny trial in Finland. Phenotypic and genotypic correlations between wood quality traits were low to moderate, and varied by site. For 
wood quality traits this means that a single value is not representative, and that selection for one trait will not impact another.

Pilodyn's north and south values were highly correlated, and a single value should be sufficient for later assessment in silver birch field trails. Practical issues meant that taking two measurements per stem face was helpful, especially as the tool sometimes slipped or misfired. A second value can help to identify errors and provide more accurate estimates. Hyssna had higher growth, and lower Pilo and AV values, in agreement with studies of birch wood properties where faster growth rates reduced density $[19,20]$ and strength [18]. However, the plots of diameter against density showed a poor relationship and a low correlation (phenotypic correlations were also low) meaning this difference is likely due to site conditions. In agreement with other studies, growth rate seemingly had no effect on wood density $[87,88]$, but did vary by site. Itrax density and Pilodyn penetration were moderately correlated, although this relationship could be improved with more observations. The level of accuracy provided by Pilodyn has been sufficient for genetics trials comparing families, but not for comparing individuals within families [40]. Selection for the best trees to clone may be improved by using detailed density information, as provided by core scanning or destructive sampling.

The average DENS Itrax values were $431 \mathrm{~kg} \mathrm{~m}^{-3}$ at Hyssna and $444 \mathrm{~kg} \mathrm{~m}^{-3}$ at Brunsberg. Some comparable studies of juvenile silver birch $[10,19,81]$ had average density values of: $478 \mathrm{~kg} \mathrm{~m}^{-3}$ for 22-year-old Finnish provenance trials [81], $455 \mathrm{~kg} \mathrm{~m}^{-3}$ for Latvian plantation-grown birch for ages 11 to 15 years [19], and of $429 \mathrm{~kg} \mathrm{~m}^{-3}$ for 11-year-old Swedish birch clones [10]. The density values obtained in this report are similar to other studies, yet there is variation within families, and often even within a stem $[20,89]$, which is ignored when average values are used.

\section{Conclusions}

Pilodyn penetration was under strong genetic control, and grain angle had moderate heritabilities with high genotypic variation. This indicates that there is the potential to improve grain angle through breeding. However, low genotypic variation for Pilodyn measurements indicate that it will be harder to improve Pilodyn penetration through breeding, and consequently harder to influence wood density. Genotypic and phenotypic correlations between growth traits measured at different ages were high, indicating that early selection is possible for size traits. Low genotypic and phenotypic correlations between NDT measurements and growth traits indicate that wood quality traits cannot be improved by indirect selection. The high genetic correlations between sites suggest that grain angle, Pilodyn penetration and acoustic velocity values are determined by genotype rather than by environment. The results of the study indicate that NDT tools can be applied to silver birch genetics programs, yet more studies are needed to confirm their usefulness. The measurements for grain angle seem to have the greatest potential for improvement, while Pilodyn penetration also shows promise for inclusion. Pilodyn penetration was moderately correlated with wood density. The measurement was relatively quick and can be applied to a large number of individuals. No unfavorable correlations were observed between wood density and diameter, as are often observed in coniferous species. A broader study is needed to identify and quantify the effects of variables which could influence NDT measurements in birch genetics trials. Further work should also explore the possible relationships between bark height and size/wood quality traits. High between site genetic correlations support the use of NDT tools for comparing traits between families, but more accurate or destructive methods may be required to select individual trees.

Author Contributions: Conceptualization, G.J., M.L. and S.A.; methodology, G.J., M.L. and S.A.; software, G.J. and M.L.; validation, G.J. and M.L.; formal analysis, M.L.; investigation, G.J. and J.L.; resources, J.L., M.L. and S.A.; data curation, G.J.; writing-original draft preparation, G.J., M.L. and S.A.; writing-review and editing, G.J., M.L. and S.A.; visualization, G.J. and M.L.; supervision, M.L. and S.A.; project administration, M.L. and S.A.; funding acquisition, M.L. and S.A. All authors have read and agreed to the published version of the manuscript. 
Funding: This work was financed by the research program FRAS-The Future Silviculture in Southern Sweden. The project is a collaboration between the Swedish University of Agriculture Science (SLU), Linnaeus University and Skogforsk (the Forestry Research Institute of Sweden). This research was also funded by the Kungl. Skogs-och Lantbruksakademien, grant number GFS2018-0073.

Data Availability Statement: The measurements used in this report are also being analyzed separately for a study of the effect of stem form on NDT properties and measurements. Data can be made available to interested parties after this report is produced.

Conflicts of Interest: The authors declare no conflict of interest.

\section{Appendix A}

Table A1. Parents which were crossed to produce offspring. The ' $\mathrm{X}$ ' mark indicates mother and father ID for the resulting offspring used in this study. Unique genotype IDs and names have been substituted for numbers. Tree 66 was used both as a mother and a father tree.

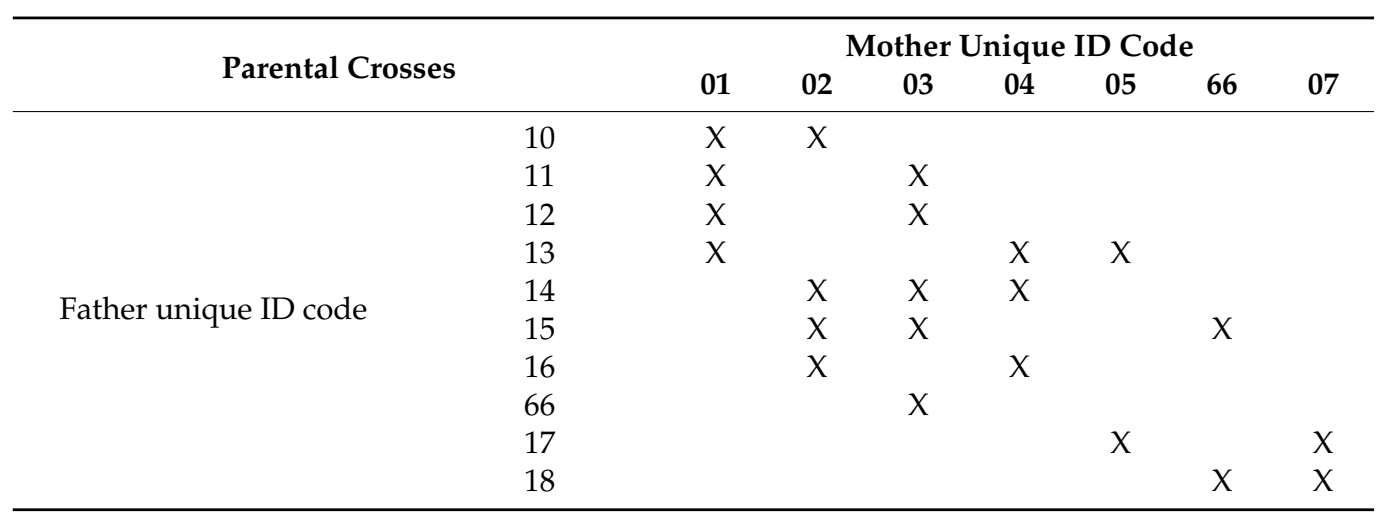

\section{References}

1. SLU. Forest Statistics 2019; Swedish University of Agricultural Sciences: Umeå, Sweden, 2019; p. 138.

2. Woxblom, L.; Nylinder, M. Industrial utilization of hardwood in Sweden. Ecol. Bull. 2010, 53, 43-50.

3. Götmark, F.; Fridman, J.; Kempe, G.; Norden, B. Broadleaved tree species in conifer-dominated forestry: Regeneration and limitation of saplings in southern Sweden. For. Ecol. Manag. 2005, 214, 142-157. [CrossRef]

4. Holmström, E.; Karlsson, M.; Nilsson, U. Modeling birch seed supply and seedling establishment during forest regeneration. Ecol. Model. 2017, 352, 31-39. [CrossRef]

5. Hynynen, J.; Niemistö, P.; Viherä-Aarnio, A.; Brunner, A.; Hein, S.; Velling, P. Silviculture of birch (Betula pendula Roth and Betula pubescens Ehrh.) in northern Europe. For. Int. J. For. Res. 2010, 83, 103-119. [CrossRef]

6. Cameron, A.D.; Dunham, R.A.; Petty, J.A. The effects of heavy thinning on stem quality and timber properties of silver birch (Betula pendula Roth). For. Int. J. For. Res. 1995, 68, 275-286. [CrossRef]

7. Heräjärvi, H.; Verkasalo, E. Timber grade distribution and relative stumpage value of mature Finnish Betula pendula and B. pubescens when applying different bucking principles. For. Prod. J. 2002, 52, 40-51.

8. Heräjärvi, H. Technical properties of mature birch (Betula pendula and B. pubescens) for saw milling in Finland. Silva Fenn. 2001, 35, 469-485. [CrossRef]

9. Heräjärvi, H. Variation of basic density and Brinell hardness within mature Finnish Betula pendula and B. pubescens stems. Wood Fiber Sci. 2004, 36, 216-227.

10. Stener, L.-G.; Hedenberg, Ö. Genetic parameters of wood, fibre, stem quality and growth traits in a clone test with Betula pendula. Scand. J. For. Res. 2003, 18, 103-110. [CrossRef]

11. Rosvall, O. Review of the Swedish Tree Breeding Program; Skogforsk: Uppsala, Sweden, 2011.

12. Zeltinšs, P.; Matisons, R.; Gailis, A.; Jansons, J.; Katrevičs, J.; Jansons, Ā. Genetic Parameters of Growth Traits and Stem Quality of Silver Birch in a Low-Density Clonal Plantation. Forests 2018, 9, 52. [CrossRef]

13. Rosvall, O.; Jansson, G.; Andersson, B.; Ericsson, T.; Karlsson, B.; Sonesson, J.; Stener, L.-G. Genetiska Vinster i Nuvarande Och Framtida fröPlantager Och Klonbladningar; Uppsala BioCentre: Uppsala, Sweden, 2001.

14. Eriksson, G. Betula Pendula and Betula Pubescens: Recent Genetic Research; Uppsala BioCentre, Department of Plant Biology and Forest Genetics: Uppsala, Sweden, 2011.

15. Hong, Z.; Fries, A.; Wu, H.X. High negative genetic correlations between growth traits and wood properties suggest incorporating multiple traits selection including economic weights for the future Scots pine breeding programs. Ann. For. Sci. 2014, 71, 463-472. [CrossRef] 
16. Wu, H.X.; Sanchez, L. Effect of selection method on genetic correlation and gain in a two-trait selection scheme. Aust. For. 2011, 74, 36-42. [CrossRef]

17. Kennedy, S.G.; Cameron, A.D.; Lee, S.J. Genetic relationships between wood quality traits and diameter growth of juvenile core wood in Sitka spruce. Can. J. For. Res. 2013, 43, 1-6. [CrossRef]

18. Dunham, R.; Cameron, A.; Petty, J. The effect of growth rate on the strength properties of sawn beams of silver birch (Betula pendula Roth). Scand. J. For. Res. 1999, 14, 18-26. [CrossRef]

19. Liepiòð, K.; Rieksts-Riekstiòð, J. Stemwood density of juvenile silver birch trees (Betula pendula Roth) from plantations on former farmlands. Balt. For. 2013, 19, 179-186.

20. Bhat, K. Variation in structure and selected properties of Finnish birch wood. 1: Interrelationships of some structural features, basic density and shrinkage [Betula pendula, B. pubescens]. Silva Fenn. 1980, 14, 384-396. [CrossRef]

21. Johansson, M.; Säll, H.; Lundqvist, S.-O. Properties of Materials from Birch-Variations and Relationships: Part 2. Mechanical and Physical Properties; Linnaeus University: Växjö, Sweden, 2013.

22. Apiolaza, L. Very early selection for solid wood quality: Screening for early winners. Ann. For. Sci. 2009, 66, 601. [CrossRef]

23. Chauhan, S.; Aggarwal, P. Segregation of Eucalyptus tereticornis Sm. clones for properties relevant to solid wood products. Ann. For. Sci. 2011, 68, 511. [CrossRef]

24. Kien, N.D.; Jansson, G.; Harwood, C.; Almqvist, C.; Thinh, H.H. Genetic variation in wood basic density and Pilodyn penetration and their relationships with growth, stem straightness, and branch size for Eucalyptus urophylla in Vietnam. N. Z. J. For. Sci. 2008, 38, 160-175.

25. Fundova, I.; Funda, T.; Wu, H.X. Non-destructive wood density assessment of Scots pine (Pinus sylvestris L.) using Resistograph and Pilodyn. PLoS ONE 2018, 13, e0204518. [CrossRef] [PubMed]

26. Fundova, I.; Funda, T.; Wu, H.X. Non-destructive assessment of wood stiffness in Scots pine (Pinus sylvestris L.) and its use in forest tree improvement. Forests 2019, 10, 491. [CrossRef]

27. Chen, Z.-Q.; Karlsson, B.; Lundqvist, S.-O.; García Gil, M.R.; Olsson, L.; Wu, H.X. Estimating solid wood properties using Pilodyn and acoustic velocity on standing trees of Norway spruce. Ann. For. Sci. 2015, 72, 499-508. [CrossRef]

28. Blackburn, D.; Hamilton, M.; Williams, D.; Harwood, C.; Potts, B. Acoustic wave velocity as a selection trait in Eucalyptus nitens Forests 2014, 5, 744. [CrossRef]

29. Warren, E.; Smith, R.G.B.; Apiolaza, L.A.; Walker, J.C.F. Effect of stocking on juvenile wood stiffness for three Eucalyptus species. New For. 2009, 37, 241-250. [CrossRef]

30. Fundova, I.; Hallingbäck, H.; Jansson, G.; Wu, H. Genetic Improvement of Sawn-Board Stiffness and Strength in Scots Pine (Pinus sylvestris L.). Sensors 2020, 20, 1129. [CrossRef] [PubMed]

31. Hallingbäck, H.R.; Jansson, G.; Hannrup, B.; Fries, A. Which annual rings to assess grain angles in breeding of Scots pine for improved shape stability of sawn timber. Silv Fenn. 2010, 44, 275-288. [CrossRef]

32. Hallingbäck, H.R.; Jansson, G.; Hannrup, B. Genetic parameters for grain angle in 28-year-old Norway spruce progeny trials and their parent seed orchard. Ann. For. Sci. 2008, 65, 1. [CrossRef]

33. Toulmin, M.J.; Raymond, C. Developing a sampling strategy for measuring acoustic velocity in standing Pinus radiata using the TreeTap time of flight tool. N. Z. J. For. Sci. 2007, 37, 96.

34. Wu, H.X.; Powell, M.B.; Yang, J.L.; Ivković, M.; McRae, T.A. Efficiency of early selection for rotation-aged wood quality traits in radiata pine. Ann. For. Sci. 2007, 64, 1-9. [CrossRef]

35. Jayawickrama, K.J.S. Breeding radiata pine for wood stiffness: Review and analysis. Aust. For. 2001, 64, 51-56. [CrossRef]

36. Gao, S.; Wang, X.; Wiemann, M.C.; Brashaw, B.K.; Ross, R.J.; Wang, L. A critical analysis of methods for rapid and nondestructive determination of wood density in standing trees. Ann. For. Sci. 2017, 74, 27. [CrossRef]

37. Llana, D.F.; Short, I.; Harte, A.M. Use of non-destructive test methods on Irish hardwood standing trees and small-diameter round timber for prediction of mechanical properties. Ann. For. Sci. 2020, 77, 1-13. [CrossRef]

38. Wessels, C.; Malan, F.S.; Rypstra, T. A review of measurement methods used on standing trees for the prediction of some mechanical properties of timber. Eur. J. For. Res. 2011, 130, 881-893. [CrossRef]

39. Jacquin, P.; Longuetaud, F.; Leban, J.-M.; Mothe, F. X-ray microdensitometry of wood: A review of existing principles and devices. Dendrochronologia 2017, 42, 42-50. [CrossRef]

40. Raymond, C.A.; MacDonald, A.C. Where to shoot your pilodyn: Within tree variation in basic density in plantation Eucalyptus globulus and E. nitens in Tasmania. New For. 1998, 15, 205-221. [CrossRef]

41. Baliuckienè, A.; Baliuckas, V. Genetic variability of silver birch (Betula pendula L.) wood hardness in progeny testing at juvenile age. Balt. For. 2006, 12, 134-140.

42. Stackpole, D.J.; Vaillancourt, R.E.; de Aguigar, M.; Potts, B.M. Age trends in genetic parameters for growth and wood density in Eucalyptus globulus. Tree Genet. Genomes 2010, 6, 179-193. [CrossRef]

43. Raymond, C.A.; Henson, M.; Pelletier, M.-C.; Boyton, S.; Joe, B.; Thomas, D.; Smith, H.; Vanclay, J.K. Improving Dimensional Stability in Plantation-Grown E. pilularis and E. dunnii; FWPA Report PN06.3017; Forest \& Wood Products: Melbourne, Australia, 2009.

44. Cornelius, J. Heritabilities and additive genetic coefficients of variation in forest trees. Can. J. For. Res. 1994, 24, 372-379. [CrossRef]

45. Mannes, D.; Lehmann, E.; Cherubini, P.; Niemz, P. Neutron imaging versus standard X-ray densitometry as method to measure tree-ring wood density. Trees 2007, 21, 605-612. [CrossRef] 
46. Greaves, B.L.; Borralho, N.M.; Raymond, C.A.; Farrington, A. Use of a Pilodyn for the indirect selection of basic density in Eucalyptus nitens. Can. J. For. Res. 1996, 26, 1643-1650. [CrossRef]

47. Björklund, J.; von Arx, G.; Nievergelt, D.; Wilson, R.; Van den Bulcke, J.; Günther, B.; Loader, N.; Rydval, M.; Fonti, P.; Scharnweber, T. Scientific merits and analytical challenges of tree-ring densitometry. Rev. Geophys. 2019, 57, 1224-1264. [CrossRef]

48. Cown, D.; Haslett, A.; Kimberley, M.; McConchie, D. The influence of wood quality on lumber drying distortion. Ann. For. Sci. 1996, 53, 1177-1188. [CrossRef]

49. Luostarinen, K.; Verkasalo, E. Birch as Sawn Timber and in Mechanical Further Processing in Finland. A Literature Study. Silva Fenn. Monogr. 2000, 1, 40.

50. Kretschmann, D.E.; Bridwell, J.J.; Nelson, T.C. Effect of changing slope of grain on ash, maple, and yellow birch in bending strength. In Proceedings of the WCTE 2010, World Conference on Timber Engineering, Riva del Garda, Italy, $20-24$ June 2010.

51. Harris, J.M. Non-destructive assessment of spiral grain in standing trees. N. Z. J. For. Sci. 1984, 14, 395-399.

52. Hannrup, B.; Säll, H.; Jansson, G. Genetic parameters for spiral grain in Scots pine and Norway spruce. Silvae Genetica 2003, 52, 215-220.

53. Hallingbäck, H.R.; Jansson, G.; Hannrup, B. Genetic correlations between spiral grain and growth and quality traits in Picea abies. Can. J. For. Res. 2010, 40, 173-183. [CrossRef]

54. Murphy, G.; Cown, D. Stand, stem and log segregation based on wood properties: A review. Scand. J. For. Res. 2015, 30, 757-770. [CrossRef]

55. Downes, G.M.; Gwinyai Nyakuengama, J.; Evans, R.; Northway, R.; Blakemore, P.; Dickson, R.L.; Lausberg, M. Relationship between wood density, microfibral angle and stiffness in thinned and fertilized Pinus radiata. IAWA J. 2002, 23, 253-265. [CrossRef]

56. Auty, D.; Achim, A. The relationship between standing tree acoustic assessment and timber quality in Scots pine and the practical implications for assessing timber quality from naturally regenerated stands. For. Int. J. For. Res. 2008, 81, 475-487. [CrossRef]

57. Wang, X.; Ross, R.J.; McClellan, M.; Barbour, R.J.; Erickson, J.R.; Forsman, J.W.; McGinnis, G.D. Strength and Stiffness Assessment of Standing Trees Using a Nondestructive Stress Wave Technique; Research Paper FPL-RP-585; United States Department of Agriculture, Forest Service, Forest Products Laboratory: Madison, WI, USA, 2000.

58. Wang, X. Acoustic measurements on trees and logs: A review and analysis. Wood Sci. Technol. 2013, 47, 965-975. [CrossRef]

59. Armstrong, J.P.; Patterson, D.W.; Sneckenberger, J.E. Comparison of three equations for predicting stress wave velocity as a function of grain angle. Wood Fiber Sci. 2007, 23, 32-43.

60. Mason, E.G.; Hayes, M.; Pink, N. Validation of ultrasonic velocity estimates of wood properties in discs of radiata pine. N. Z. J. For. Sci. 2017, 47, 1-5. [CrossRef]

61. Legg, M.; Bradley, S. Measurement of stiffness of standing trees and felled logs using acoustics: A review. J. Acoust. Soc. Am. 2016, 139, 588-604. [CrossRef] [PubMed]

62. Grabianowski, M.; Manley, B.; Walker, J. Acoustic measurements on standing trees, logs and green lumber. Wood Sci. Technol. 2006, 40, 205-216. [CrossRef]

63. Mora, C.R.; Schimleck, L.R.; Isik, F.; Mahon, J.M.; Clark, A.; Daniels, R.F. Relationships between acoustic variables and different measures of stiffness in standing Pinus taeda trees. Can. J. For. Res. 2009, 39, 1421-1429. [CrossRef]

64. Weather Spark. Available online: https:/ / weatherspark.com/countries/SE (accessed on 5 January 2021).

65. Ewertson, M. Resultat från avkommeprövning av plusträd av vårtbjörk (Betula pendula). 2014, Volume 2013, p. 15. Available online: https:/ / stud.epsilon.slu.se/6458/ (accessed on 29 December 2020).

66. Russo, D.; Marziliano, P.A.; Macrì, G.; Zimbalatti, G.; Tognetti, R.; Lombardi, F. Tree Growth and Wood Quality in Pure Vs. MixedSpecies Stands of European Beech and Calabrian Pine in Mediterranean Mountain Forests. Forests 2019, 11, 6. [CrossRef]

67. Hallingbäck, H.R.; Högberg, K.-A.; Säll, H.; Lindeberg, J.; Johansson, M.; Jansson, G. Optimal timing of early genetic selection for sawn timber traits in Picea abies. Eur. J. For. Res. 2018, 137, 553-564. [CrossRef]

68. Bergsten, U.; Lindeberg, J.; Rindby, A.; Evans, R. Batch measurements of wood density on intact or prepared drill cores using x-ray microdensitometry. Wood Sci. Technol. 2001, 35, 435-452. [CrossRef]

69. Gilmour, A.; Gogel, B.; Cullis, B.; Thompson, R. ASReml User Guide Release 3.0; VSN International Ltd.: Hemel Hempstead, UK, 2009.

70. Isik, F.; Holland, J.; Maltecca, C. Genetic Data Analysis for Plant and Animal Breeding; Springer International Publishing AG: Cham, Switzerland, 2017.

71. Skogsstyrelsens. Forestry Statistics Database; Skogsstyrelsens: Jönköping, Sweden, 2019.

72. Dubois, H.; Verkasalo, E.; Claessens, H. Potential of Birch (Betula pendula Roth and B. pubescens Ehrh.) for Forestry and Forest-Based Industry Sector within the Changing Climatic and Socio-Economic Context of Western Europe. Forests 2020, 11, 336. [CrossRef]

73. Ekö, P.-M.; Johansson, U.; Petersson, N.; Bergqvist, J.; Elfving, B.; Frisk, J. Current growth differences of Norway spruce (Picea abies), Scots pine (Pinus sylvestris) and birch (Betula pendula and Betula pubescens) in different regions in Sweden. Scand. J. For. Res. 2008, 23, 307-318. [CrossRef]

74. Bergh, J.; Nilsson, U.; Kjartansson, B.; Karlsson, M. Impact of climate change on the productivity of silver birch, Norway spruce and Scots pine stands in Sweden and economic implications for timber production. Ecol. Bull. 2010, 53, $185-196$. 
75. Felton, A.; Gustafsson, L.; Roberge, J.M.; Ranius, T.; Hjältén, J.; Rudolphi, J.; Lindbladh, M.; Weslien, J.; Rist, L.; Brunet, J.; et al. How climate change adaptation and mitigation strategies can threaten or enhance the biodiversity of production forests: Insights from Sweden. Biol. Conserv. 2016, 194, 11-20. [CrossRef]

76. Li, Y.; Suontama, M.; Burdon, R.D.; Dungey, H.S. Genotype by environment interactions in forest tree breeding: Review of methodology and perspectives on research and application. Tree Genet. Genomes 2017, 13, 60. [CrossRef]

77. Eriksson, G.; Ekberg, I.; Clapham, D. Genetics Applied to Forestry: An Introduction; Genetic Centre, Department of Plant Biology and Forest Genetics: Uppsala, Sweden, 2013.

78. Stener, L.-G.; Jansson, G. Improvement of Betula pendula by clonal and progeny testing of phenotypically selected trees. Scand. J. For. Res. 2005, 20, 292-303. [CrossRef]

79. Gailis, A.; Zeltiňš, P.; Purviňš, A.; Augustovs, J.; Vīndedzis, V.; Zarina, I.; Jansons, Ā. Genetic parameters of growth and quality traits in open-pollinated silver birch progeny tests. Silva Fenn. 2020, 54, 10220. [CrossRef]

80. Skrøppa, T.; Solvin, T.M. Genetic variation and inheritance in a $9 \times 9$ diallel in silver birch (Betula pendula). Scand. J. For. Res. 2019, 34, 178-188. [CrossRef]

81. Viherä-Aarnio, A.; Velling, P. Growth, wood density and bark thickness of silver birch originating from the Baltic countries and Finland in two Finnish provenance trials. Silva Fenn. 2017, 51, 18. [CrossRef]

82. Hannrup, B.; Grabner, M.; Karlsson, B.; Mueller, U.; Rosner, S.; Wilhelmsson, L.; Wimmer, R. Genetic parameters for spiral-grain angle in two 19-year-old clonal Norway spruce trials. Ann. For. Sci. 2002, 59, 551-556. [CrossRef]

83. Thinley, C.; Palmer, G.; Vanclay, J.K.; Henson, M. Spiral and interlocking grain in Eucalyptus dunnii. Holz als Roh-und Werkst. 2005, 63, 372-379. [CrossRef]

84. Liang, D.; Zhang, X.; Wang, C.; Wang, X.; Li, K.; Liu, G.; Zhao, X.; Qu, G.-Z. Evaluation of Betula platyphylla Families Based on Growth and Wood Property Traits. For. Sci. 2018, 64, 663-670. [CrossRef]

85. Chen, Z.-Q.; Hai, H.N.T.; Helmersson, A.; Liziniewicz, M.; Hallingbäck, H.R.; Fries, A.; Berlin, M.; Wu, H.X. Advantage of clonal deployment in Norway spruce (Picea abies (L.) H. Karst). Ann. For. Sci. 2020, 77, 14. [CrossRef]

86. Kumar, S.; Lee, J. Age-age correlations and early selection for end-of-rotation wood density in radiata pine. For. Genet. 2002, 9 , 323-330.

87. Giagli, K.; Vavrcik, H.; Fajstavr, M.; Černý, J.; Novosadová, K.; Martiník, A. Stand factors affecting the wood density of naturally regenerated young silver birch growing at the lower altitude of the Czech Republic region. Wood Res. 2019, 64, 1011-1022.

88. Velling, P. Wood density in two Betula pendula Roth progeny trials. Folia For. 1979, 416, 1-24.

89. Dobrowolska, E.; Wroniszewska, P.; Jankowska, A. Density Distribution in Wood of European Birch (Betula pendula Roth.). Forests 2020, 11, 445. [CrossRef] 